\title{
TREATMENT OF ARSENIC RICH WATERS BY THE HDS PROCESS
}

\author{
Matthew Dey ${ }^{1}$, Keith Williams ${ }^{2}$ and Richard Coulton ${ }^{3}$ \\ ${ }^{I}$ SRK Consulting (UK) Ltd, Cardiff, UK \\ ${ }^{2}$ School of Engineering, Cardiff University, $U K$ \\ ${ }^{3}$ Unipure Europe Ltd, Monmouth, UK
}

\begin{abstract}
Arsenic contaminated waters are not uncommon; indeed from naturally occurring contaminated waters through to those that are a direct consequence of human activities such as mining, all are affecting the quality of water resources worldwide. The ever increasing demands on natural water resources mean that the effective control of this toxic contaminant is paramount and this is reflected in the ever increasing global legislation.

There are currently three mechanisms by which arsenic is commercially treated in effluents. These are physical separation processes such as reverse osmosis, precipitation/adsorption processes, some of which are bacterially assisted, and a whole variety of ion exchange processes, again with some bacterial enhancement. The choice of treatment is not only driven by cost but by the chemistry of the water and the water quality standard to be met. In this study a very high arsenic enriched groundwater, containing in excess of $25,000 \mu \mathrm{g} / \mathrm{L}$ arsenic, was treated by a typical treatment method through a continuously operated pilot plant. In the treatment, iron III salts were added to the influent in order to form precipitates with the arsenic and to form an adsorptive surface that would assist with treatment of the enriched water. This addition of iron III salts for the removal of arsenic is common practice in the water treatment industry as the resulting iron III arsenates are highly stable.

However, results from the pilot plant show that the process was further enhanced by the small addition hydrogen peroxide. Hydrogen peroxide is a powerful oxidising reagent and assists in ensuring the complete conversion of any arsenic III to arsenic V that was then effectively removed in the pilot plant. After treatment residual arsenic levels of $10 \mu \mathrm{g} / \mathrm{L}$ were obtained compared to $68 \mu \mathrm{g} / \mathrm{L}$ without oxidation reagent addition.
\end{abstract}

\section{Introduction}

Arsenic contaminated waters are widespread and the occurrence of naturally contaminated waters is well documented for virtually every continent. This is because arsenic is the twentieth most abundant element in the earth's crust. Concentrations of arsenic in the earth's crust vary, but average concentrations are generally reported to range from 1.5 to $5 \mathrm{mg} / \mathrm{kg}$ and arsenic is a major constituent of many mineral species in both igneous and sedimentary rocks (US-EPA, 2000 and references there in). These sources determine the regional levels of arsenic in both ground and surface waters.

Arsenic has several valence states that are: $-3,0,+1,+3$, and +5 , of which the +3 and +5 states are the most abundant found in a variety of minerals and natural waters. Many of the chemical behaviours of arsenic are linked to the ease of conversion between +3 and +5 valence states. The valence state also affects the toxicity of arsenic compounds, while arsine ( -3$)$ is the most toxic, the following are successively less toxic: organo-arsines, arsenites (+3), arsenates (+5), arsonium metals (+1), and elemental arsenic (0) (US-EPA, 2000).

Various treatment methods such as sorption/precipitation, ion exchange, and membrane separation have been proposed and adopted for the removal of arsenic from aqueous solutions (Seidel et al., 2005) and for the in-situ stabilisation of arsenic within the point of source.

Of these available processes the precipitation process was chosen for this investigation as generally this process is the most cost effective and efficient approach for arsenic removal (Bowell, 2003).

\section{Methodology}

For the test work program a sample of approximately 400 litres of groundwater containing over $25,000 \mu \mathrm{g} / \mathrm{L}$ arsenic as a major contaminant was collected (see Table 1 for details). The sample was stored in a $1 \mathrm{~m}^{3}$ sealed plastic container (IBC) for the duration of the test work and into which liquid nitrogen was added daily in order to preserve the sample as far as possible by minimising oxidation.

The pilot plant utilised in the assessment is a scaled version of the high density sludge (HDS) operation (see Fig. 1 where a photograph of the pilot plant is shown). The pilot plant consists of three reactors in series, followed by a vessel for flocculation and finally a conical thickener/clarifier. As can be seen in Figure 1 all of the vessels were provided with suitable agitation. The approximate working volumes of the first three reactors were 5 litres each, whilst the flocculation vessel was about 3 litres and the thickener dimensions were $0.2 \mathrm{~m}$ diameter at top by $0.6 \mathrm{~m}$ deep. The sample groundwater flow through the pilot plant was kept constant at 10 litres per hour throughout the test work. 


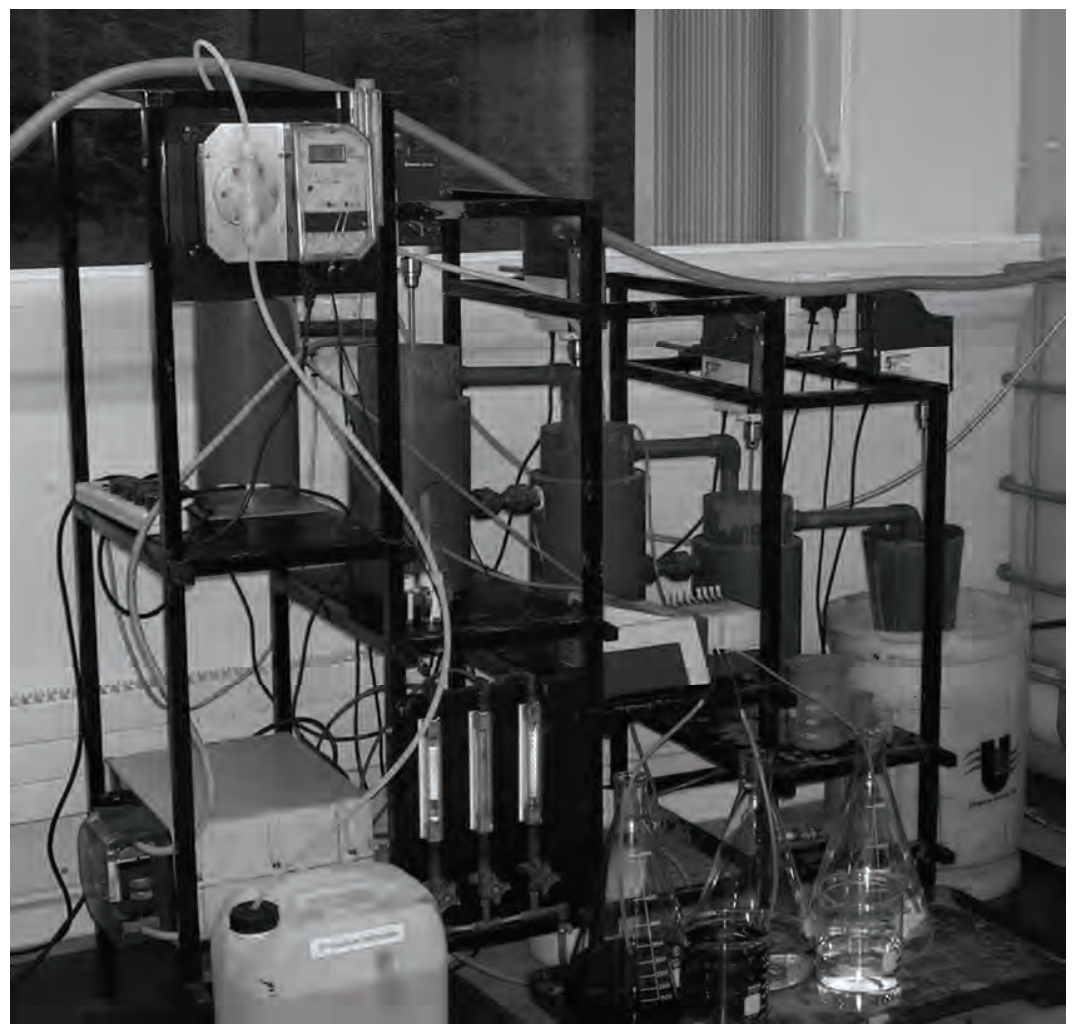

Figure 1. The pilot plant in the laboratory at the Cardiff School of Engineering.

Precipitated and thickened sludge was returned from the thickener to the second reactor (normally the first reactor in the standard HDS plant configurations from Unipure) by a peristaltic pump and $\mathrm{pH}$ control was automated with sodium hydroxide (technical grade) addition to maintain a $\mathrm{pH}$ of 7.0. During the tests no attempt was made to optimise thickened sludge return rate, other than to maintain the solids concentration near to $4 \% \mathrm{w} / \mathrm{v}$. The flocculant used throughout the trail was Ciba Magnafloc 155 dosed at a consistent rate of $8 \mathrm{mg} / \mathrm{L}$ with respect to the forward groundwater flow. Both iron III sulfate and hydrogen peroxide (both technical grade) were utilised through the pumping of stock solutions (the large conical flasks in the foreground of the Fig. 1) to the first reactor. Unless otherwise stated the thickener overflow was visually clear during all of the runs performed.

Initial trials on the pilot plant enabled the determination of the most suitable chemical reagent addition dosages. However, in view of the relatively small sample size, these initial runs were quite short (typically 4 hours) and were performed with a seeding of high density sludge from the Wheal Jane water treatment plant in Cornwall. The solids concentration in the reactors varied between 3.8 and $4.7 \% \mathrm{w} / \mathrm{v}$.

Following this initial phase the plant was operated for as long as possible with the remaining water sample in the absence of any seeding with HDS to establish steady state concentrations of the target elements in solution and to generate sufficient solids for determination of their stability.

Unless otherwise stated, all chemical analyses were performed in the School of Engineering using the Perkin Elmer DV2100 ICP OES in the most sensitive axial mode.

\section{Results and Discussion}

The concentrations of a suite of cations in the feed material are presented in Table 1, confirming the presence of elevated levels of arsenic but no other obvious pollutants.

Results from the initial trials suggested that a suitable dosage of iron III sulfate was $100 \mathrm{mg} / \mathrm{L}$ equivalent in the groundwater forward flow giving a ratio of arsenic to iron of 1:4. This is in agreement with other researchers (Bowell, 2003 and references therein) that arsenic removal increased with an increasing presence of iron (II) or (III). For this test work the most commercially favourable results were taken.

For the test work program five runs through the pilot plant were undertaken with each one at a fixed $\mathrm{pH}$ and iron (III) addition, only the dosage of hydrogen peroxide varied. Table 2 lists the experiments undertaken with the pilot plant. 
Table 1. Sample groundwater chemistry.

\begin{tabular}{cc}
\hline Element & Concentration $\mathrm{mg} / \mathrm{L}$ \\
\hline $\mathrm{As}$ & 25.16 \\
$\mathrm{Ca}$ & 95.33 \\
$\mathrm{Cu}$ & 0.06 \\
$\mathrm{Fe}$ & $\mathrm{ND}$ \\
$\mathrm{Mg}$ & 1.12 \\
$\mathrm{Mn}$ & $\mathrm{ND}$ \\
$\mathrm{Zn}$ & $\mathrm{ND}$ \\
Note - the ICP was operated in the radial mode, ND is not detected in this mode.
\end{tabular}

Table 2. Pilot plant test regimes.

\begin{tabular}{cccc}
\hline Test & $\begin{array}{c}\text { Target } \\
\mathrm{pH}\end{array}$ & Fe III mg/L equivalent & $\mathrm{H}_{2} \mathrm{O}_{2} \mathrm{mg} / \mathrm{L}$ equivalent \\
\hline 1 & 7.0 & 100 & 0 \\
2 & 7.0 & 100 & 51.0 \\
3 & 7.0 & 100 & 25.5 \\
4 & 7.0 & 100 & 12.8 \\
5 & 7.0 & 100 & 5.1 \\
\hline
\end{tabular}

For the first test the iron (III) sulfate is utilised as the oxidant in the system; results across all the reactors are shown in Table 3.

Table 3. Results of arsenic removal by pilot plant with only $\mathrm{Fe}_{2}\left(\mathrm{SO}_{4}\right)_{3}$ addition.

\begin{tabular}{llllll}
\hline Element & \multicolumn{5}{c}{ Concentration $(\mathrm{mg} / \mathrm{L})$ in the liquids filtered at $0.45 \mu \mathrm{m}$} \\
\cline { 2 - 6 } & $\mathrm{R} 1$ & $\mathrm{R} 2$ & $\mathrm{R} 3$ & $\begin{array}{l}\text { Flocculation } \\
\text { vessel }\end{array}$ & $\begin{array}{l}\text { Thickener } \\
\text { Overflow }\end{array}$ \\
\hline $\mathrm{As}$ & 9.03 & 0.26 & 0.22 & 0.19 & 0.68 \\
$\mathrm{Cu}$ & 0.30 & 0.05 & 0.04 & 0.03 & 0.20 \\
$\mathrm{Fe}$ & 7.71 & $\mathrm{ND}$ & $\mathrm{ND}$ & $\mathrm{ND}$ & 0.29 \\
$\mathrm{Mg}$ & 1.13 & 4.27 & 4.51 & 5.00 & 4.47 \\
$\mathrm{Mn}$ & 0.25 & 0.28 & 0.26 & 0.24 & 0.26 \\
$\mathrm{Zn}$ & 0.01 & 0.13 & 0.12 & 0.12 & 0.16 \\
$\mathrm{pH}$ & 3.27 & 7.80 & 7.87 & 7.90 & 7.92 \\
\hline
\end{tabular}

Of particular note was the fact that no sodium hydroxide was used during any of the first four tests. This was due to the existing buffering that arose from the Wheal Jane sludge used to seed the pilot plant. The initial $\mathrm{pH}$ decrease in R1 is due to the addition of the iron (III) sulfate, when the acidity is neutralised in R2 with the recirculated sludge most of the metals of interest are removed. As the groundwater passes through the plant the levels continue to decrease until the discharge from the thickener. Here there is an increase in the filtered metal content suggesting at some instability in the formed sludge. In studying arsenic removal by iron (III) other researchers (Tozawa et al., 1977; Robbins et al., 1988; Robbins, 2001) found iron (III) more effective in the treatment of arsenic (V) than arsenic (III) and that arsenic (V) is removed over a wider pH range.

Over the next three tests the addition of hydrogen peroxide was investigated, at differing dosages. The idea of using hydrogen peroxide is to include an additional oxidising reagent to the iron (III) and thereby ensure a higher degree of oxidation of any arsenic (III) species to arsenic (V). The following equation shows the oxidation of the arsenic (III) ion.

$$
\mathrm{H}_{2} \mathrm{O}_{2}+\mathrm{AsO}_{3}{ }^{3-} \rightarrow \mathrm{H}_{2} \mathrm{O}+\mathrm{AsO}_{4}{ }^{3-}
$$

The results are shown in Table 4. The addition of hydrogen peroxide improves the removal of arsenic and this is notable in R1 were the typical arsenic reading has decreased from over $9 \mathrm{mg} / \mathrm{L}$ to less than $300 \mu \mathrm{g} / \mathrm{L}$. The decrease in detectable arsenic then continues through all the reactors and remains low in the final discharge, although yet again there is a slight increase in the effluent discharged. However, this is not as notable as that from the initial test.

Other researchers (Tozawa and Nishimura, 1976) found rapid oxidation rates of arsenic (III) with hydrogen peroxide under alkaline solutions but slower rates at $\mathrm{pH}<6$. As the $\mathrm{pH}$ of $\mathrm{R} 1$ is dominated by the low $\mathrm{pH}$ of the 
iron (III) sulfate low reaction rates would be expected but as there is a rapid rise in $\mathrm{pH}$ into the next reactor R2, with the addition of the recirculated sludge, then any remaining reactions should be completed. However, Bowell (2003) reported high initial rates of arsenic removal in conjunction with either $\mathrm{Fe}$ (II) or Fe(III) additions but that these rapidly decreased and that this decrease was more pronounced with a higher starting concentration of arsenic. Thereby suggesting that most of the oxidation by hydrogen peroxide occurs in R1 and that the reactions in $\mathrm{R} 2$ relate to further oxidation by iron (III).

Table 4. Results of arsenic removal with the addition of hydrogen peroxide.

\begin{tabular}{llllll}
\hline Run 2 & \multicolumn{5}{c}{ Concentration $(\mathrm{mg} / \mathrm{L})$ in the liquids filtered at $0.45 \mu \mathrm{m}$} \\
\cline { 2 - 6 } $\begin{array}{c}51 \mathrm{mg} / \mathrm{L} \\
\mathrm{H}_{2} \mathrm{O}_{2}\end{array}$ & $\mathrm{R} 1$ & $\mathrm{R} 2$ & $\mathrm{R} 3$ & $\begin{array}{l}\text { Flocculation } \\
\text { vessel }\end{array}$ & $\begin{array}{l}\text { Thickener } \\
\text { Overflow }\end{array}$ \\
equiv & & & & & \\
\hline $\mathrm{As}$ & 0.30 & 0.04 & 0.03 & 0.03 & 0.05 \\
$\mathrm{Cu}$ & 0.04 & $\mathrm{ND}$ & $\mathrm{ND}$ & 0.01 & $\mathrm{ND}$ \\
$\mathrm{Fe}$ & 5.80 & 0.13 & 0.15 & 0.03 & 0.53 \\
$\mathrm{Mg}$ & 1.20 & 8.30 & 8.97 & 9.67 & 9.26 \\
$\mathrm{Mn}$ & 0.26 & 0.08 & 0.08 & 0.07 & 0.07 \\
$\mathrm{Zn}$ & 0.46 & 0.05 & 0.06 & 0.05 & 0.11
\end{tabular}

\begin{tabular}{llllll}
\multirow{2}{*}{$\begin{array}{l}\text { Run } 3 \\
\begin{array}{c}25.5 \mathrm{mg} / \mathrm{L} \\
\mathrm{H}_{2} \mathrm{O}_{2}\end{array}\end{array}$} & $\mathrm{5}$ Concentration $(\mathrm{mg} / \mathrm{L})$ in the liquids filtered at $0.45 \mu \mathrm{m}$ \\
\cline { 2 - 6 }$\quad$ equiv & & $\mathrm{R} 2$ & $\mathrm{R} 3$ & $\begin{array}{l}\text { Flocculation } \\
\text { vessel }\end{array}$ & $\begin{array}{l}\text { Thickener } \\
\text { Overflow }\end{array}$ \\
\hline $\mathrm{As}$ & 0.03 & 0.06 & 0.09 & 0.04 & 0.07 \\
$\mathrm{Cu}$ & 0.20 & $\mathrm{ND}$ & 0.01 & 0.01 & $\mathrm{ND}$ \\
$\mathrm{Fe}$ & 7.01 & 0.64 & 0.29 & 0.38 & 1.00 \\
$\mathrm{Mg}$ & 1.13 & 7.25 & 7.31 & 9.76 & 7.39 \\
$\mathrm{Mn}$ & 0.26 & 0.19 & 0.20 & 0.10 & 0.18 \\
$\mathrm{Zn}$ & 0.02 & 0.19 & 0.35 & 0.12 & 0.24
\end{tabular}

\begin{tabular}{llllll}
\multirow{2}{*}{$\begin{array}{l}\text { Run } 4 \\
12.8 \mathrm{mg} / \mathrm{L} \\
\begin{array}{l}\mathrm{H}_{2} \mathrm{O}_{2} \\
\text { equiv }\end{array}\end{array}$} & $\mathrm{R} 1$ & $\mathrm{R} 2$ & $\mathrm{R} 3$ & $\begin{array}{l}\text { Flocculation } \\
\text { vessel }\end{array}$ & $\begin{array}{l}\text { Thickener } \\
\text { Overflow }\end{array}$ \\
\cline { 2 - 6 } $\mathrm{As}$ & 0.14 & 0.03 & 0.02 & 0.02 & 0.01 \\
$\mathrm{Cu}$ & 0.10 & 0.02 & 0.03 & 0.01 & 0.01 \\
$\mathrm{Fe}$ & 5.44 & $\mathrm{ND}$ & $\mathrm{ND}$ & $\mathrm{ND}$ & $\mathrm{ND}$ \\
$\mathrm{Mg}$ & 1.12 & 6.46 & 6.24 & 7.35 & 6.51 \\
$\mathrm{Mn}$ & 0.25 & 0.25 & 0.23 & 0.17 & 0.23 \\
$\mathrm{Zn}$ & 0.03 & 0.09 & 0.08 & 0.07 & 0.09 \\
\hline
\end{tabular}

For the last test the plant was drained and all the formed solids and Wheal Jane sludge were removed. The plant was then restarted and was run with just the groundwater sample with iron (III) and hydrogen peroxide, with the forming solids been recirculated. In this way any effect from the pre-formed sludge from Wheal Jane could be negated. The data are presented in Table 5.

During the test an equivalent of $5.1 \mathrm{mg} / \mathrm{L}$ of hydrogen peroxide was added and sodium hydroxide was required to correct $\mathrm{pH}$, as the forming sludge contained little buffering capacity. During this trial an equivalent of $31 \mathrm{mg} / \mathrm{L} \mathrm{NaOH}$ of groundwater treated was used.

The high levels seen in R1 are probably remnants from the cleaning regime; however, the test as a whole still produced good results with an overall discharge of $60 \mu \mathrm{g} / \mathrm{L}$, an order of magnitude lower than the test using no hydrogen peroxide. 
Table 5. Results of arsenic removal for Test 5.

\begin{tabular}{cccccc}
\hline Element & \multicolumn{5}{c}{ Concentration $(\mathrm{mg} / \mathrm{L})$ in the liquids filtered at $0.45 \mu \mathrm{m}$} \\
\cline { 2 - 6 } & $\mathrm{R} 1$ & $\mathrm{R} 2$ & $\mathrm{R} 3$ & $\begin{array}{c}\text { Flocculation } \\
\text { vessel }\end{array}$ & $\begin{array}{c}\text { Thickener } \\
\text { Overflow }\end{array}$ \\
\hline $\mathrm{As}$ & 3.13 & 0.02 & 0.05 & 0.03 & 0.06 \\
$\mathrm{Cu}$ & 0.61 & 0.02 & 0.02 & 0.02 & 0.02 \\
$\mathrm{Fe}$ & $329.5^{*}$ & 0.07 & 0.06 & 0.02 & $\mathrm{ND}$ \\
$\mathrm{Mg}$ & 1.46 & 1.50 & 1.45 & 1.41 & 1.42 \\
$\mathrm{Mn}$ & $1.65^{*}$ & 0.51 & 0.41 & 0.38 & 0.23 \\
$\mathrm{Zn}$ & 0.17 & 0.21 & 0.13 & 0.14 & 0.05 \\
\hline
\end{tabular}

* probably the result of dissolution of some residual precipitates from this tank or sample contamination with the feed solution of iron sulphate

\section{Conclusions}

This paper gives an overview of the potential to treat very high arsenic enriched effluents using the HDS process with the addition of reagents. Although not fully optimised the tests show promising results for a substantial reduction in levels arsenic in the discharged effluent with the minimal addition of reagents.

The addition of hydrogen peroxide aids the treatment of the arsenic by oxidising the arsenic (III) present to arsenic $(\mathrm{V})$. This is then more effectively removed by the co-precipitation/adsorption with the additional iron (III) added to the process system.

However, one point of importance but not addressed in this paper are the improved settling and dewatering characteristics created by using the high density sludge process compared to a conventional single pass operation. These characteristics will enhance this treatment process and provide a superior sludge in terms of handle-ability for disposal.

\section{Acknowledgements}

The lead author wishes to acknowledge the kind permission of Unipure Europe Ltd for the publication the results of these tests and the laboratory staff in the CLEER facilities at Cardiff University.

\section{References}

Bowell R. (2003). The influence of speciation in the removal of arsenic from mine waters. Land Contam. \& Reclam. 11(2), 231-238.

Robbins R.G. (2001). Some chemical aspects relating to arsenic remedial technologies. Plenary Lecture USEPA Workshop on Managing Arsenic Risks to the Environment: Characterisation of Waste, Chemistry and Treatment and Disposal. Denver, Colorado, USA, May 1-4.

Robbins R.G., Huang J.C.Y., Nishimura T., Khoe G.H., (1988). The adsorption of arsenate ion by ferric hydroxide. In: Reddy, R.G. et al. (Eds) Arsenic Metallurgy - Fundamentals and Applications. The Metallurgical Soc Inc, Warrendale, Pennsylvania, USA. 99-112.

Seidel H., Gorsch K., Amstatter K., Mattusch J. (2005). Immobilisation of arsenic in a tailings material by ferrous iron treatment. Water Research 39, 4073-4082.

Tozawa K., Nishimura T. (1976). Oxidation of As (III) to As (V) in aqueous solutions. J. Mining and Metallurgy in Japan 92, 1066, 809-814.

Tozawa K., Nishimura T., Umestsu Y. (1977). Removal of arsenic from aqueous solutions. Canadian Inst. of Metallurgy, 16th Conference, Vancouver, Canada.

US EPA (2000). Arsenic occurrence in public drinking water supplies. EPA-815-R-00-023. 